\title{
KONFLIK KEPENTINGAN ELIT POLITIK LOKAL DALAM PROYEK PEMBANGUNAN : STUDI KASUS PROVINSI BENGKULU TAHUN ANGGARAN 2017
}

\author{
Zakaria Habib Al-Ra'zie*); Heru Wahyudi \\ Program Studi Administrasi Negara Universitas Sutomo, Serang, Banten \\ *)email: zhalrazie@gmail.com
}

Paper Accepted: 25 Desember 2021
Paper Reviewed: 01-06 Januari 2022
Paper Edited: 08-15 Januari 2022
Paper Approved: 17 Januari 2022

\section{PENDAHULUAN}

Otonomi daerah memberikan kesempatan bagi masyarakat lokal untuk menentukan sendiri arah kebijakan daerahnya melalui pemerintahan yang demokratis, (Syamsuddin Haris, 2007: 10). Meskipun secara konseptual UndangUndang Nomor 23 Tahun 2014 menyatakan bahwa otonomi daerah bertujuan untuk percepatan peningkatan kesejahteraan masyarakat melalui aktiftas yang efisien, inovatif dan kreatif, namun tidak sedikit kepala daerah yang terpilih secara demokratis malah melakukan penyelewengan kekuasaan dan membuat kebijakan manipulatif yang menentang kehendak masyarakat (Syamsuddin Haris,2006: 156-157), seperti melakukan 
korupsi dengan memburu rente dari para pengusaha atas jatah proyek yang dimenangkan.

Di Provinsi Bengkulu korupsi politik cenderung tidak lepas dari pengaruh kepala daerah. Kasus terakhir adalah operasi tangkap tangan (OTT) KPK terhadap Gubernur Bengkulu Ridwan Mukti (20162018) terkait dugaan suap dalam pengaturan proyek pembangunan jalan raya di beberapa wilayah di Provinsi Bengkulu yang dikelola Dinas Pekerjaan Umum dan Penataan Ruang (PUPR) Provinsi Bengkulu untuk Tahun Anggaran (TA) 2017, (Abdul Aziz, 2018).

Kasus tersebut melengkapi korupsi 3 kali berturut-turut yang dilakukan Gubernur Bengkulu sejak dimulainya Pilkada langsung 2005. Dimulai dari Agusrin M Najamuddin (2005-2012) atas kasus korupsi pajak bumi dan bangunan serta bea perolehan hak atas tanah bangunan tahun anggaran 2006, (Detik.com,2012), Junaidi Hamzah (20122015) atas kasus korupsi penerbitan SK pembayaran honor Tim Pembina RSUD M Yunus Bengkulu, (Alexander Haryanto,2017), dan Ridwan Mukti (20162018) yang selanjutnya disingkat RM, atas kasus suap fee proyek pembangunan jalan di Provinsi Bengkulu.

Kasus tersebut melibatkan diantaranya istri RM, Lily Martiani Maddari sebagai makelar (broker), Rico Diansari dan Jhoni Wijaya sebagai pengusaha pemenang lelang proyek yang melakukan suap, dan Rico Kadafi saudara kandung Lily Martiani Maddari yang juga berperan sebagai mekelar dalam kasus tersebut. bawahannya di kepengurusan DPD Golkar Bengkulu

Padahal, satu bulan setelah dilantik RM menggelar seremoni besar "Penandatanganan Pakta Integritas Anti Korupsi dan Anti Narkoba" yang diikuti oleh 1.108 pejabat struktural di lingkungan Pemprov Bengkulu. Acara tersebut bahkan dihadiri juga oleh Ketua Komisi Pemberantasan Korupsi (KPK) Agus Rahardjo, Kepala Badan Narkotika Nasional (BNN) Budi Waseso, mantan Ketua Mahkamah Konstitusi (MK) Mahfud MD, Ketua Ombudsman RI Amzulian Rifai dan Kapolda Bengkulu Brigjen Pol M. Ghufron, (Firmansyah, 2017). Disampaikan RM, penandatanganan pakta integritas tersebut adalah komitmen terbuka agar janji-janji para pejabat di lingkup Provinsi Bengkulu termasuk Gubernur dan Wakil Gubernur secara moral bisa dipertanggungjawabkan.

Pada TA 2017 Provinsi Bengkulu memiliki program pembangunan jalan di sejumlah tempat di beberapa kabupaten dan kota. Tercatat paket proyek tersebut dimenangkan oleh sejumlah perusahaan, namun dalam proses lelang sempat terjadi konflik antara Gubernur Bengkulu RM dan Kepala Dinas PUPR Provinsi Bengkulu Kuntadi yang selanjutnya disingkat KUN, dalam penentuan pemenang paket proyek tersebut, (Putusan Sidang Jhoni Wijaya, 2017: 28).

Kemudian, dari sejumlah paket proyek itu, tiga proyek yang dimenangkan PT. Statika Mitra Sarana (PT.SMS Grup) dalam prosesnya melibatkan para makelar (broker) yang menghubungkan RM dan para pengusaha pemenang proyek. Selanjutnya untuk menjamin kelancaran pelaksanaan proyek itu dilakukan praktik suap terhadap sejumlah pemangku kebijakan di Provinsi Bengkulu, (Putusan Sidang Rico Diansari, 2017: 28).

\section{Identifikasi Masalah}

Pada 2017 Provinsi Bengkulu memiliki program pembangunan jalan di sejumlah tempat di beberapa kabupaten dan kota. Paket proyek tersebut dimenangkan oleh sejumlah perusahaan yakni (1) PT. Statika Mitra Sarana (PT.SMS), (2) PT. Sarana Mitra Saudara (PT. SMS Grup), (3) PT. Rico Putra Selatan, (4) PT. Rivo Putra Mandiri Kerjasama Operasional (KSO) dengan PT. Sumber Alam Makmur Sejati (PT. SAM), (5) PT. Sumber Alam Makmur Sejati (PT. SAM), (6) PT. Peu Putra Agung, (7) CV. Dwi Karya KSO PT. Peu Putra Agung, (8) PT. Pulau Batu Intan, (9) CV. Pagar Bintang KSO PT. Praja Mandiri, dan (10) PT. Pilar Jaya Konstruksi, (Putusan Mahkamah Agung, 2017, Putusan Sidang Jhoni Wijaya, 2017 dan Putusan Sidang Rico Diansari, 2017). .

Dalam prosesnya, lelang terhadap sejumlah proyek tersebut menimbulkan konflik antara Gubernur Bengkulu RM dan Kepala Dinas PUPR Provinsi Bengkulu KUN, karena keduanya terindikasi memiliki kepentingan pribadi yang berbeda terhadap 
penentuan pemenang lelang proyek-proyek tersebut, (Putusan Sidang Jhoni Wijaya, 2017: 28).

Kemudian, dari sejumlah paket proyek tersebut ada 2 proyek yang dimenangkan oleh PT. Statika Mitra Sarana dan 1 proyek yang dimenangkan PT. Sarana Mitra Saudara yang merupakan grup dari PT. Statika Mitra Sarana, dalam proses setelah lelang menimbulkan konflik kepentingan yang melibatkan para makelar (broker) yang menghubungkan antara Gubernur Bengkulu RM dan pihak pengusaha pemenang proyek. Pihak pengusaha berkepentingan untuk menjamin kelancaran pelaksanaan proyek yang dimenangkan dengan melakukan suap terhadap sejumlah pemangku kebijakan di Provinsi Bengkulu, (Putusan Sidang Rico Diansari, 2017: 28).

\section{Rumusan Masalah}

Berdasarkan uraian masalah penelitian tersebut, maka rumusan masalah yang diambil adalah bagaimana konflik antara Gubernur Provinsi Bengkulu RM dan Kepala Dinas PUPR Provinsi Bengkulu KUN terkait proyek pembangunan jalan di Provinsi Bengkulu tahun anggaran 2017?

\section{METODE PENELITIAN}

Penelitian ini menggunakan metode penelitian kualitatif dengan pendekatan studi kasus. Penelitian kualitatif merupakan suatu penelitian interpretasi, asumsi, dugaan, nilai dan pendapat dari peneliti sehingga membuat hasil penelitian menjadi lebih jelas dan mendalam (J. W Creswell, 1994:134).

Penelitian kualitatif menghasilkan data deskriptif berupa narasi baik tertulis maupun lisan dari hasil pengamatan perilaku maupun pernyataan lisan objek penelitian. Penelitian kualitatif tidak menggunakan sumber data matematis atau hitungan seperti data statistik, melainkan memanfaatkan data berupa narasi dan dokumentasi baik tertulis maupun tidak tertulis. Penelitian kualitatif bertujuan memahami fenomena yang dialami subjek penelitian seperti perilaku, motivasi, persepsi dan lainnya secara holistik pada konteks khusus yang alamiah dengan berbagai metode alamiah, (Moleong, 2007:6).

Jenis penelitian ini paling sesuai dengan tema penelitian yang diambil yakni tentang fenomena politik yang berlangsung sangat dinamis. Melalui penelitian ini fenomena apapun yang dikaji baik alamiah maupun hasil rekayasa manusia dapat digambarkan dengan baik. (Suripto 2016:87).

Penelitian ini mengambil studi kasus di Provinsi Bengkulu dengan fokus kajian pada Pemerintah Provinsi Bengkulu yakni Gubernur Bengkulu dan dinas PUPR Provinsi Bengkulu. Sumber data pada penelitian ini berasal dari data sekunder yang dikumpulkan dari dokumen putusan sidang pengadilan subjek penelitian atau aktor-aktor terkait yang memuat fakta-fakta persidangan dalam bentuk narasi langsung para aktor maupun temuan pihak penyidik.

Data diperoleh dari dari bagian arsip Pengadilan Negeri Tindak Pidana Korupsi Bengkulu yang beralamat di Kota Bengkulu dan juga di unduh dari website Mahkamah Agung RI. Data tambahan diambil dari dokumentasi media cetak dan online baik lokal maupun nasional, juga melalui pustaka lain dari buku-buku, jurnal, dan sumber lain yang dinilai relevan serta dapat dipertanggungjawabkan.

\section{HASIL DAN PEMBAHASAN \\ Teori Konflik}

Pada umumnya konflik dimaknai sebagai benturan atau pertentangan di antara dua sesuatu atau lebih. Dalam bahasa latin Webster meyebut conflict berarti benturan antara beberapa pihak dalam bentuk perkelahian, peperangan atau perjuangan. Konflik juga bisa dimaknai sebagai persepsi berbagai pihak tentang perbedaan kepentingan di antara mereka yang tidak memiliki titik temu, (Dean G. Pruitt dan Jeffrey Z. Rubin,2009: 9).

Sementara Geist mendefinisikan konflik sebagai bentuk ketidaksepakatan, perbedaan pendapat, perbedaan interpretasi, persaingan untuk menguasai sesuatu dan karena adanya perspektif ganda, (William F. Eadie, Paul E. Nelson, 2001: 60). Adapun Karl Cordell dan Stefan Wolff (2009: 4-5) mendeskrpsikan konflik sebagai suatu kondisi ketika dua aktor atau lebih mengejar tujuan yang tidak saling cocok (incompatible), namun dari perspektif individu mereka sepenuhnya adil (fair)..

Sementara Duncan Williamson menyebut konflik kepentingan sebagai kondisi ketika seseorang yang memiliki 
posisi sebagai petugas publik, pagawai, maupun seorang professional, yang memiliki kepentingan pribadi yang hendak diwujudkan dengan mempengaruhi tujuan dan pelaksanaan dari tugas-tugas resmi dari institusinya. Konflik kepentingan ini mencerminkan suatu situasi yang memiliki potensi untuk mengganggu bahkan merusak objektifitas atau ketidakkeberpihakan seseorang tersebut karena adanya kemungkinan benturan atau bercampurnya antara kepentingan pribadi dan kepentingan tugas atau tanggungjawab resmi yang semestinya dikerjakan, (Dwi Budi Sulistiyana, Gotfridus Goris Seran, 2016: 5)

\section{Penyebab dan Tujuan Konflik}

Berdasarkan cara berpikir kausalitatif, konflik yang dilihat sebagai akibat tidak mungkin muncul tanpa didahului oleh sebab yang menjadikannya ada. Dari pemikiran yang berkembang disebutkan ada enam alasan utama penyebab terjadinya konflik antara lain; para pihak terkait memiliki tujuan yang berbeda, alasan solidaritas yang tinggi, memang terorganisir untuk berkonflik, mampu mengendalikan sumberdaya konflik yang dimiliki, karena permusuhan terhadap lawan mereka, dan bisa juga karena faktor perebutan sumberdaya material, (Ottomar J. Bartos \& Paul Wehr, 2002: 9-10).

Adapun tujuan konflik umumnya untuk mendapatkan dan mempertahankan sesuatu atau sumberdaya untuk kepentingan hidup. Pada batas minimal konflik berguna untuk mempertahankan hidup dan pada tingkat selanjutnya konflik berfungsi sebagai upaya meningkatkan kualitas atau kenyamanan hidup. Namun konflik tersebut tidak hanya sebatas kepentingan material tubuh, melainkan juga untuk keperluan yang terkait dengan kejiwaan atau rohani seperti harga diri dan posisi kehormatan dalam masyarakat. Dengan demikian yang diperjuangkan dalam konflik tidak hanya wilayah tempat tinggal, kekayaan dan kekuasaan yang bersifat empiris saja, melainkan juga harga diri, keselamatan hidup, dan orang-orang yang dicintai serta hal-hal lain yang sifatnya emosional, (Fera Nugroho, Pradjarto Dirdjosanjoto, Nico L. Kana,2004: 22)

\section{Konflik Kepentingan Gubernur dan Kadis PUPR Provinsi Bengkulu}

Ada puluhan paket proyek di Bidang Bina Marga Dinas PUPR Provinsi Bengkulu pada TA 2017. Proyek tersebut terdiri dari 50 paket jalan dengan total anggaran sekitar Rp. 500 miliar dan paket jembatan sebanyak 11 paket dengan anggaran Rp. 100 miliar, (Putusan Sidang Jhoni Wijaya, 2017:31). Semua paket proyek dilelang secara bertahap di bawah tanggungjawab dinas PUPR Provinsi Bengkulu yang dipimpin Kepala Dinas PUPR KUN.

Dalam prosesnya sejumlah proyek yang selesai di lelang menjadi penyebab konflik antara Gubernur Bengkulu RM dan Kadis PUPR KUN, karena tidak semua pengusaha yang memenangkan proyek tersebut sesuai dengan keinginan RM. Kedua pihak terindikasi memiliki kepentingan pribadi yang berbeda terhadap penentuan pemenang lelang proyek-proyek tersebut.

Dari total 61 paket proyek yang tersedia ada 16 proyek yang sudah di lelang dan semuanya merupakan paket proyek pembangunan jalan di beberapa daerah di Provinsi Bengkulu.

Latar belakang konflik kepentingan antara RM dan KUN penelti temukan berawal dari rencana RM yang mencari orang untuk ditempatkan menjadi Pelaksana Tugas Kepala Dinas (Plt. Kadis) PUPR Provinsi Bengkulu.

Pada pertengahan September 2016 KUN datang ke rumah pribadi RM di Kota Bengkulu dan keduanya membicarakan tentang tawaran RRM untuk menjadikan KUN sebagai Pelaksana Tugas Kepala Dinas PUPR Provinsi Bengkulu. Dalam pertemuan tersebut RM menegaskan semua hal yang terkait dengan pekerjaan dinas PU nanti dikoordinasikan dengan Rico Kadafi yang merupakan adik kandung istri RM, Lily Martiani Maddari. RM mengatakan pada KUN : "Pak Kun dalam hal pekerjaan kePU-an nanti koordinasi dengan Rico, adik ibu." Kemudian dilanjutkan dalam bahasa Jawa, "ojo lali, lek ono susuk'e,", (Putusan Sidang Jhoni Wijaya, 2017:31) yang berarti jangan lupa kalau ada sisanya. Pernyataan tersebut bermakna RM meminta KUN untuk mengatur perusahaan pemenang lelang proyek sesuai dengan keinginannya 
saat KUN resmi menjabat di dinas PUPR nanti. Selain itu secara implisit dalam bahasa Jawa RM juga meminta KUN memberikan uang bagian untuk dirinya dari proyekproyek tersebut.

Latar belakang konflik antara RM dan KUN karena keinginan RM yang tidak difasilitasi oleh KUN, padahal sebelumnya KUN berjanji untuk mengkondisikan para pemenang lelang proyek di dinas PUPR Provinsi Bengkulu TA 2017 adalah orangorang yang ditunjuk RM sebagaimana list rekanan yang diperlihatkan Rico Kadafi saat pertemuan dengan aktor KUN di Mall Plaza Senayan lantai 2 pada Maret 2017. Saat pertemuan itu KUN masih menjabat sebagai Plt. Kadis PUPR Provinsi Bengkulu.

Koflik kepentingan kedua pihak tersebut terkait pengaturan pemenang lelang proyek untuk mendapatkan keuntungan finansial yang disebut sebagai commitmen fee atau fee proyek sebesar 10 persen dari setiap paket proyek yang dimenangkan masingmasing pengusaha.

RM ingin mengembalikan biaya politik yang sudah banyak dikeluarkan pada kontestasi Pilkada Gubernur Provinsi Bengkulu 2015 lalu. Pada pertemuan 5 Juni 2017 di kantor Gubernur RM mengatakan :

"Saya ini ikut Pilkada berdarahdarah, habis ratusan milyar, emang kalian dimana selama ini? Janganjangan kalian lawan, bukan pendukung saya? Kenapa ga pamit sama Saya? Saya ini mantan pengusaha dan sudah dua periode jadi Bupati, ini sekarang Saya jadi Gubernur, Saya penguasa di Bengkulu", (Putusan Sidang Rico Diansari, 2017: 39-40).

RM marah karena menduga terjadi kolusi antara KUN selaku Kadis PUPR dengan para kontraktor. RM menyebut banyak dari kontraktor-kontraktor tersebut yang merupakan pendukung lawan politiknya saat pilkada, dan KUN sendiri tidak memiliki jasa atau konstribusi apapun pada aktor saat kontestasi politik tersebut, (Putusan Sidang Jhoni Wijaya, 2017: 56). RM mengatakan pada para kontraktor :

"Jangan macam-macam dengan staf Saya, staf saya nanti Saya tempelang. Nanti Saya bikin bangkrut kalian, di blacklist perusahaannya, Saya $\begin{gathered}\text { putus } \\ \text { kontrakkan semua.", }\end{gathered}$ (Putusan
Sidang Rico Diansari, 2017: 40).

RM mencurigai ada kejanggalan oleh KUN sejak pertemuan mereka di kediaman pribadi RM di Kota Bengkulu pada 30 Mei 2017, sebab RM tidak menerima laporan perkembangan lelang proyek dari Dinas PUPR Provinsi Bengkulu berbentuk nota dinas yang mestinya secara berkala harus dilaporkan dinas PUPR pada Gubernur secara berjenjang dari Asisten hingga Sekda, (Putusan Sidang Jhoni Wijaya, 2017: 54). Pada pertemuan itu RM meminta laporan dari KUN soal lelang proyek yang sudah dilaksanakan. KUN melaporkan pemenangnya adalah dua pengusaha yakni Ahmad Irfansyah selaku Direktur PT. Sumber Alam Makmur Sejati (PT. SAM) mendapat 2 paket proyek dan Rico Diansari selaku Direktur PT. Rico Putra Selatan (Putusan Sidang Rico Diansari, 2017: 57) yang juga tim sukses RM saat Pilkada juga mendapat 2 paket proyek, (Putusan Sidang Jhoni Wijaya, 2017: 56). Rico Diansari juga bawahan RM dalam kepengurusan DPD Golkar Bengkulu, RM Ketua DPD dan Rico Diansari Bendahara.

Selanjutnya RM meminta KUN memperbaiki laporan tersebut karena dinilai tidak sinkron dan ada yang ditutup-tutupi, (Putusan Sidang Rico Diansari, 2017:: 36), sebab laporan itu hanya diberikan dalam bentuk coretan-coretan yang menurut RM tidak lengkap, (Putusan Sidang Jhoni Wijaya, 2017: 56).

Sementara dari pihak KUN, peneliti menemukan indikasi bahwa dia berkepantingan untuk mendapatkan keuntungan finansial dari pengaturan pemenang lelang proyek versi dirinya sendiri yang berbeda dengan keinginan RM. KUN bersandiwara di hadapan RM dengan seolaholah memenuhi perintah RM namun kenyataannya tidak demikian.

Menurut keterangan Plt. Kadis PUPR Provinsi Bengkulu pengganti KUN, Octaviano, KUN dan Kabid Bina Marga Dinas PUPR Provinsi Bengkulu Syaifudin Firman diduga menerima janji fee Rp. 1,5 miliar dari Jhoni Wijaya sebagai balas budi karena meloloskan perusahaannya sebagai pemenang lelang proyek di dinas PUPR 
Provinsi Bengkulu. Saat itu 12 Juni 2017

Jhoni Wijaya menghadap Octaviano di kantor dinas PUPR Provinsi Bengkulu dan mengatakan : "ada yang mesti disiapkan Pak? Sebentar lagi lebaran. Kalau Pak Kun sama Pak Undin sudah Rp. 1,5 miliar setelah uang muka pekerjaan sudah cair", (Yuliardi Hardjo Putro, 2017). Namun Octaviano tidak mengetahui dan tidak pula menanyakan uang tersebut untuk siapa saja apakah untuk pajabat di PU sendiri atau untuk pihak lain, (Putusan Sidang Rico Diansari, 2017: 56).

Selain menerima janji fee dari pengusaha Jhoni Wijaya, KUN dan Syaifudin Firman juga menerima fee sebesar Rp. 600 juta dari pengusaha Ahmad Irfansyah yang perusahaannya juga diloloskan KUN memenangkan proyek pembangunan jalan. Berdasarkan keterangan Ahmad Irfansyah, dia dihubungri Rico Diansari yang meminta fee 10 persen sesuai permintaan Gubernur RM. Namun Ahmad Irfansyah mengatakan dia sedang tidak memiliki dana sebab sudah habis diberikan pada aktor KUN selaku Kadis PUPR dan Saifudin Firman selaku Kabid Bina Marga sebesar Rp. 600 juta untuk keperluan pengurusan lelang proyek, (Putusan Sidang Rico Diansari, 2017: 49).

Dalam konflik kepentingan fee proyek ini peneliti menemukan kolusi antara KUN dan Syaifudin Firman. Keduanya sepakat bekerjasama mengejar kepentingan yang berbeda dengan keinginan RM. Berdasarkan hal itu KUN dinilai peneliti membangun loyalitas ganda dalam tubuh birokrasi Dinas PUPR Provinsi Bengkulu. KUN mengondisikan Syaifudin Firman untuk loyal pada dirinya sebagai Kadis PUPR Provinsi Bengkulu ketimbang pada RM selaku Gubernur Provinsi Bengkulu yang membawahi semua dinas di tingkat Provinsi.

Syaifudin Firman sendiri mengaku pernah menawarkan proyek yang ada di Provinsi Bengkulu pada Jhoni Wijaya tanpa sepengetahuan atau arahan dari RM melainkan atas dasar inisiatifnya sendiri, (Putusan Sidang Rico Diansari, 2017: 59). Selain itu dia juga memanfaatkan posisinya sebagai Kabid Bina Marga Dinas PUPR Provinsi Bengkulu dengan mengancam membatalkan kontrak proyek yang sudah dimenangkan PT. Pilar Jaya Konstruksi yang dpipimpin Rahmani Saifullah, (Putusan Sidang Rico Diansari, 2017: 70)

Indikasi kolusi antara KUN dan Syaifudin Firman diketahui saat KUN memerintahkan Syaifudin Firman supaya tidak hadir ke Jakarta memenuhi panggilan RM pada 1 Juni 2017, (Putusan Sidang Jhoni Wijaya, 2017: 29). KUN juga meminta Syaifudin Firman untuk tidak menghubungi kontraktor pemenang proyek supaya hadir memenuhi panggilan RM ke Jakarta. Padahal KUN pada pertemuan sebelumnya di kediaman pribadi RM di bengkulu pada akhir Mei 2017 pada saat rapat bersama dengan Kadis PU, Karo Pembangunan, Kadis Pemberdayaan Masyarakat dan Desa memerintahkan Syaifudin Firman untuk menghubungi dan mengumpulkan rekanan pemenang proyek untuk hadir di Jakarta menemui RM pada 1 Juni 2017, (Putusan Sidang Jhoni Wijaya, 2017: 29).

Kemudian pada 1 Juni 2017 sekitar pukul 09.00 WIB pagi di ruang kerja Kepala Dinas PUPR Provinsi Bengkulu dilakukan teken kontrak beberapa paket proyek antara Pemprov Bengkulu yang diwakili aktor KUN selaku Pengguna Anggaran (PA) dan Syaifudin Firman selaku Pejabat Pembuat Komitmen (PPK) dengan kontraktor pemenang proyek antara lain Rico Diansari selaku Direktur PT. Rico Putra Selatan, Jhoni Wijayaselaku Direktur PT. Sarana Mitra Saudara, Ahmad Irfansyah selaku Direktur PT. Sumber Alam Makmur Sejati dan Haryanto alias Lolak selaku Direktur PT. Peu Putra Agung.

Setelah penandatanganan kontrak KUN menyampaikan pada para kontraktor untuk menemui RM di Jakarta pada hari itu juga, (Putusan Sidang Rico Diansari, 2017: 37-38). Namun kontraktor yang merespon dan hadir hanya 2 orang dari keseluruhan yang sudah memenangkan kontrak yakni Rico Diansari dan satu kontraktor lain yang sudah teken kontrak sebelumnya yakni Rahmani Saifullah selaku Direktur PT. Pilar Jaya Konstruksi yang ditemani stafnya Teza Arizal, (Putusan Sidang Rico Diansari, 2017: 38) sebab saat itu kontraktor lain sengaja tidak dihubungi oleh Syaifudin Firman sehingga tidak mengatahui akan dilakukan pertemuan malam itu juga di Jakarta. Hal tersebut dilakukan Syaifudin Firman karena mematuhi perintah KUN selaku atasannya di 
dinas PUPR supaya jangan menghubungi kontraktor karena Gubernur RM memiliki wacana akan mengganti kontraktor yang menang dengan kontraktor pilihan Gubernur sendiri, (Putusan Sidang Rico Diansari, 2017: 58). Aktor KUN pun juga tidak hadir pada pertemuan di Jakarta tersebut.

Setelah itu Syaifudin Firman mendapat perintah lagi atas nama Gubernur RM untuk mengumpulkan kontraktor pemenang proyek di kantor Pemprov Bengkulu pada 5 Juni 2017. Namun perintah tersebut bukan melalui Kepala Dinas PUPR melainkan Kepala Biro Pembangunan Daerah. Selesai rapat itu Syafrudin Firman langsung pulang ke kantor dan beberapa hari kemudian dia dan KUN digeser posisinya oleh RM tidak tidak lagi menjabat di dinas PUPR Provinsi Bengkulu, (Putusan Sidang Jhoni Wijaya, 2017: 31-32).

Dicopotnya aktor KUN dan Syaifudin Firman dari jabatan di dinas PUPR Provinsi Bengkulu oleh RM merupakan imbas dari konflik kepentingan yang terjadi di antara mereka. Menurut KUN pencopotan itu akibat tidak mematuhi perintah RM untuk mengumpulkan semua kontraktor pemenang lelang proyek dan menemuinya di Jakarta, (Putusan Sidang Jhoni Wijaya, 2017: 29). Karena tidak puas dengan kinerja tersebut KUN lalu dicopot oleh RM dari Kadis PUPR Provinsi Bengkulu dan dijadikan staf ahli Gubernur, (Putusan Sidang Rico Diansari, 2017: 55). Sementara menurut RM pecopotan tersebut karena aktor KUN dan Syaifudin Firman tidak bisa mencapai target opini Wajar Tanpa Pengecualian (WTP) dari Badan Pemeriksa Keuangan (BPK) pada instansi mereka, (Putusan Sidang Jhoni Wijaya, 2017: 57). Octaviano membenarkan pernyataan RM tersebut sebab memang ada pernyataannya yang menegaskan kepala dinas yang tidak bisa mendapatkan opini WTP dari BPK akan digeser, (Putusan Sidang Rico Diansari, 2017: 55).

Kasus tersebut memperlihatkan penyalahgunaan posisi politik sebagai kepala daerah dan jaringan kekerabatan untuk mengumpulkan keuntungan ekonomi secara tidak sah. RM menggunakan kekuasaanya sebagai Gubernur untuk memerintahkan birokrat di dinas Dinas PUPR Provinsi Bengkulu supaya mengkondisikan para pemenang lelang proyek supaya mengikuti keinginannya. Dia juga mengancam para birokrat yang tidak memahami keinginannya dan patuh terhadap perintahnya sewaktuwaktu akan diberikan punishment berupa pencopotan atau mutasi jabatan ke tempat kerja yang lebih tidak strategis.

Pilkada berbiaya tinggi menjadi motivasi utama RM melakukan praktif koruptif sehingga mengalami konflik dengan KUN yang memiliki tujuan sama namun dengan motivasi korup yang berbeda. Keduanya sama-sama memanfaatkan potensi keuntungan dari paket proyek pembangunan di Provinsi Bengkulu.

Meminjam pandangan Ottomar J. Bartos \& Paul Wehr tentang enam alasan utama penyebab konflik, konflik yang terjadi antara RM dan KUN memenuhi dua dari enam alasan tersebut yakni karena memiliki tujuan yang berbeda dan memperebutkan sumberdaya material dalam hal ini fee proyek dari pengusaha. Padangan Karl Cordell dan Stefan Wolff juga mengonformasi bahwa konflik terjadi karena kedua aktor mengejar tujuan yang tidak saling cocok (incompatible) dan karena faktor kekecewaan satu aktor terhadap aktor lainnya yang tidak mampu memenuhi harapan dan tuntutan tertentu.

Dalam konteks tersebut RM merasa kecewa dengan bawahannya KUN karena tidak mempu melaksanakan janjinya meloloskan sejumlah nama pengusaha yang dipilih untuk memenangkan proyek pembangunan. KUN juga tidak mampu mengkondisikan para pemenang lelang proyek untuk membangun komitmen keuntungan bersama secara pribadi dengan RM. Dengan kata lain konflik antara keduanya akibat tidak sesuainya realisasi keuntungan fee proyek yang diterima secara pribadi dengan kalkulasi keuntungan yang sebelumnya diharapkan.

Konflik antara kedua pihak tidak hanya sebatas konflik kepentingan di antara mereka saja, melainkan juga masuk dalam kategori korupsi politik, sebab kedua aktor terindikasi melakukan penyalahgunaan kekuasaaan politik (publik) untuk kepentingan dan demi keuntungan pribadi. Sehingga korupsi yang dilakukan dipahami sebagai dorongan pribadi mereka yang bersifat material yang pastinya berbenturan dengan norma di 
masyarakat yang mengutuk praktik penyalahgunaan kekuasaan.

Kedua aktor RM dan KUN dalam penelitian ini melakukan korupsi karena tidak kuat menahan manisnya godaan jabatan yang dipegangnya di pemerintahan. Keduanya memanfaatkan jabatan tersebut untuk tujuan keuntungan pribadi yang berbeda dengan tugas resmi yang seharusnya atau disebut sebagai a real conflict of interest.

Perilaku tersebut menunjukkan objekifitas kedua aktor sebagai pejabat yang rusak karena dominasi kepentingan pribadi masing-masing. Seperti dikatakan Duncan Williamson bahwa objektifitas pejabat menjadi rusak karena bercampurnya kepentingan pibadi dengan kepentingan resmi jebatannya, terlebih dalam kasus RM dan KUN. Selain keduanya melawan tugas resminya masing-masing mereka juga saling berkonflik kepentingan untuk mendapatkan keuntungan finansial dari para pengusaha pemenang lelang proyek yang berusaha mereka kendalikan.

Berdasarkan temuan tersebut peneliti menilai konflik RM dan KUN bukan dimotivasi oleh kepentingan memenuhi kebutuhan hidup, melainkan lebih pada kepentingan untuk meningkatkan kenyamanan hidup atau gaya hidup. Sebab RM dan KUN memiliki kesejahteraan hidup yang jauh lebih baik dibandingankan kebanyakan masyarakat Bengkulu yang hidup di salah satu provinsi termiskin di Indonesia ini. Meminjam pernyataan Aristoteles perilaku demikian disebut sebagai hedonisme yang sama dengan praktik korupsi, yakni kematian dan dekadensi moral akibat mengejar kenikmatan lahiriah semata.

Kasus tersebut peneliti lihat secara sosial, politik dan ekonomi memiliki dampak yang sangat merugikan masyarakat Bengkulu. Akibat kepentingan egois para pejabat masyarakat Bengkulu tertimpa dampak negatif yang tidak mereka perbuat. Masyarakat dirugikan oleh perilaku para aktor yang mengkhianati kepercayaan menjadi pejabat publik yang seharusnya bekerja mengurusi kepentingan masyarakat bukan sibuk dengan kepentingan diri sendiri. Platon menegaskan bahwa tidak seorang pun yang bebas dari bahaya korupsi karena penyalahgunaan kekuasaan. Dengan demikian sebenarnya bisa dipahami jika kedepannya korupsi menjadi sulit dihapus, sebab sudah terbentuk lingkaran setan saling ketidakpercayaan diantara anggota masyarakat dengan pejabat.

\section{KESIMPULAN}

Konflik antara RM selaku Gubernur Provinsi Bengkulu dengan KUN selaku Kepala Dinas PUPR Provinsi Bengkulu akibat kepentingan keduanya yang berbeda dalam penetapan pemenang lelang dalam proyek pembangunan jalan di Provinsi Bengkulu tahun anggaran 2017.

Bentuk konflik yang terjadi adalah KUN bersandiwara terhadap RM dengan berpura-pura menjalankan arahan untuk mengkondisikan pemenang proyek adalah para pengusaha yang RM inginkan. Padahal KUN diam-diam menyalahi arahan tersebut dibantu bawahannya di Dinas PUPR Provinsi Bengkulu.

KUN menunggangi skenario RM dan memasukkan skenario versi kepentingannya sendiri untuk mendapatlkan fee balas jasa dari pengusaha yang dia pilih untuk dimenangkan dalam lelang proyek, yang berbeda dengan pengusaha yang dipilih RM.

Puncak konflik terjadi saat RM menyadari permainan KUN. RM kemudian mengambil respon cepat dengan memotong rantai kewenangan KUN di dinas PUPR Provinsi Bengkulu, sehingga KUN beserta bawahannya yang diajak berkomplot dimutasi RM ke posisi lain yang tidak berhubungan dengan Dinas PUPR Provinsi Bengkulu.

Pada dasarnya substansi kepentingan kedua aktor adalah sama, yakni ingin memperoleh keuntungan finansial dari para pengusaha dengan memanfaatkan pengaruh dan jabatannya masing-masing di pemerintahan. Hanya saja cara yang dilakukan keduanya berbeda dan saling bersinggungan.

Untuk memuluskan kepentingannya memperoleh fee proyek, aktor RM memanfaatkan jabatannya sebagai Gubernur Bengkulu dan menggunakan bantuan tambahan dari relasi kekeluargaan serta jaringan bisnis dan politiknya. Aktor meminta istrinya Lily Martiani Maddari dan adik iparnya Rico Kadafi untuk menjadi makelar yang menghubungkan 
kepentingannya terhadap fee proyek dengan para pengusaha yang memenangkan lelang proyek. Aktor juga memanfaatkan relasi pribadinya dengan Rico Diansari yang merupakan salah satu pengusaha pemenang proyek yang juga bawahannya di kepengurusan DPD Golkar Bengkulu untuk menjadi tangan kanannya dalam transaksi koruptif tersebut.

Dengan memanfaatkan bantuan makelar lain tersebut, eksekusi fee proyek diproyeksikan aktor RM menjadi semakin mudah, sebab ada relasi langsung atau kedekatan bisnis antara pengusaha yang mekelar dengan pengusaha murni yang dimintai fee proyek. Alasannya karena mereka sama-sama pemenang lelang proyek yang sedang berurusan dengan penguasa politik yang mendesak untuk meminta jatah finansial dari proyek yang mereka menangkan.

Penelitian ini menemukan bahwa provinsi Bengkulu yang merupakan salah satu dari 10 besar provinsi termiskin di Indonesia selama bertahun-tahun, ternyata praktik KKN masih subur dilakukan para elit dan orang dekatnya. Kasus korupsi yang menjerat Gubernur Bengkulu RM pada 2017 menjadi pelengkap tiga kali secara berturutturut Gubenur Bengkulu terjerat kasus yang sama.

Korupsi politik tersebut dilakukan dengan cara yang lebih canggih dan melibatkan banyak pihak terutama orangorang terdekat penguasa. Korupsi dalam bentuk pemberian fee dilakukan setelah proyek dimenangkan pengusaha secara baik dan legal. Sehingga korupsi fee tersebut dilakukan sebagai balas jasa bukan sebagai uang muka seperti pola lama.

Kemudian, meskipun demokrasi langsung dipuja sebagai sistem yang dipercaya memberikan keadilan dan pemerataan kesejahteraan untuk semua pihak, nyatanya praktik KKN tetap terjadi di Bengkulu. Relasi kekeluargaan, simbiosis mutualisme antara penguasa dan pengusaha, serta jaringan partai masih menjadi pola primadona dalam pengumpulan kekayaan secara tidak sah oleh para aktor. Seperti relasi Gubernur RM dan pengusaha Rico Diansari yang sama-sama pengusus inti DPD Partai Gokar Bengkulu, RM sebagai ketua partai dan Rico Diansari Bendaharanya.

Politik berbiaya tinggi saat Pilkada menjadi motivasi utama dalam melakukan korupsi, sementara tujuan mengikuti Pilkada adalah untuk mendapatkan uang yang banyak. Sehingga pola yang muncul ibarat judi dan bisnis semata.

Kemudian wacana tentang putra daerah, kesejahteraan rakyat dan pembangunan daerah hanya pemanis dan barang dagangan saat kampanye saja. Wacana tersebut berhenti pada imajinasi dan sekedar gagasan ideal, sebab tidak pernah diupayakan serius menjadi realitas sebagaimana mestinya.

Adapun kesejahteraan yang dianggap diterima masyarakat Bengkulu hanya sisasisa manis dari ampas proyek yang sudah diperas sedemikian rupa. Pembangunan dan kesejahteraan yang didapatkan masyarakat hanya sebatas percikan atau akibat tidak langsung atau dampak sampingan dari praktik utama para elit yakni korupsi dalam pembangunan daerah. Sehingga bukan sebagai tujuan utama.

Kemudian para pejabat yang korup di Bengkulu ditemukan tidak selalu bisa bekerjasama antara sesamanya untuk memuluskan korupsi tersebut supaya aman dari jeratan hukum, melainkan mereka bisa saling berkonflik karena bersaing untuk mandapatkan keuntungan finansial sebesarbesarnya dari penyalahgunaan jabatan dan jaringan mereka.

\section{DAFTAR PUSTAKA}

Aziz, Abdul. OT'T Bengkulu: Pengadilan Tinggi Perberat Vonis RM, 2018, https:/ / tirto.id/ott-bengkulu-

pengadilan-tinggi-perberat-vonisridwan-mukti-cGSZ, diakses pada 7 Desember 2021.

Bartos, Ottomar J. \& Wehr, Paul. (2002). Using Conflict Theory. UK: Cambridge University Press.

Cordell, Karl. \& Wolff, Stefan. (2009). Ethnic Conflict: Causes, Consequences, and Responses. Cambridge UK: Polity Press.

Creswell, J. W.(1994). Research Design Qualitative and Quantitative Approaches. London: Sage Publications. 
Detik.com, Susahnya Menyeret Koruptor Rp 21 M Bernama Agusrin Najamuddin, 2012 ,

http:/ / news.detik.com/berita/1812225 / susahnya-menyeret-koruptor-rp-21-mbernama-agusrin-najamuddin, diakses pada 7 Desember 2021.

Eadie, William F. \& Nelson, Paul E. (Editors). (2001). The Language of Conflict and Resolution, USA: Sage Publications, inc.

Firmansyah, Gubernur Bengkulu dan Pengkhianatan terhadap Pakta Integritas, 2017 , https:/ / regional.kompas.com/read/20 17/06/21/23364621/gubernur.bengkul u.dan.pengkhianatan.terhadap.pakta.int egritas, diakses pada 7 Desember 2021.

Galtung, Johan. (2009) "Theories of Conflict: Definitions, Dimensions, Negations, Formations". Transcend Peace University.

Haris, Syamsuddin. (2007) Desentralisasi dan Otonomi Daerah: Desentralisasi, Demokratisasi dan Akuntabilitas Pemerintahan Daerah. Jakarta: LIPI Press.

Haryanto, Alexander. Mantan Gubernur Bengkulu Junaidi Hamsyah Dihukum 1,7 Tahun Penjara, 2017, https:/ / tirto.id/mantan-gubernurbengkulu-junaidi-hamsyah-dihukum17-tahun-penjara-czKR, diakses pada 7 Desember 2021.

Moleong, Lexy J. (2007). Metodelogi Penelitian Kualitatif (edisi revisi). Bandung: PT. Remaja Rosdakarya.

Nugroho, Fera., Dirdjosanjoto, Pradjarto \& Kana, Nico L. (2004). Konflik dan Kekerasan pada Aras Lokal. Salatiga: Pustaka Percik-Pustaka Pelajar.

Peraturan Perundang-undangan Republik Indonesia Nomor 23 Tahun 2014 Tentang Pemerintahan Daerah, bagian penjelasan.

Pruitt, Dean G. dan Rubin, Jeffrey Z. (2009). Teori Konflik Sosial. Yogyakarta: Pustaka Pelajar.

Putro, Yuliardi Hardjo. Pengakuan Mengejutkan dalam Sidang Dugaan Suap Gubernur Bengkulu, 2017, https:/ / m.liputan.6.com/regional/ read /3142271/pengakuan-mengejutkandalam-sidang-dugaan-suap-gubernur- bengkulu, diakses pada 7 Desember 2021.

Putusan Terdakwa Jhoni Wijaya Nomor 33/Pid Sus TPK/2017/PN.bgl, h. 2828.

Putusan Terdakwa Rico Diansari, Nomor 46/Pid.Sus-TPK/2017/PN.BGL, h.29.

Sulistiyana, Dwi Budi. \& Seran, Gotfridus Goris. (2016). Modul Pengelolaan Konflik Kepentingan (Cetakan ke-1). Jakarta: Direktorat Pendidikan dan Pelayanan Masyarakat KPK.

Suripto. "Analisis Penyelesaian Sengketa atau Konflik Politik". Jurnal Politikologi Institute Pemerintahan Dalam Negeri, Volume 3, Nomor 1, Oktober, 2016: 81-87. 